\title{
Pengaruh Financing to Deposit Ratio (FDR) dan Non- Performing Financing (NPF) terhadap Bagi Hasil Deposito Mudharabah pada Bank Syariah Mandiri
}

\author{
Achmad Agus Yasin Fadli \\ Manajemen, Universitas Pamulang, Indonesia \\ Korespondensi penulis: agusfadli70@yahoo.com
}

\begin{abstract}
Along with the development of sharia banking institutions in Indonesia, the more types of services provided by these Islamic banking institutions. This study focuses on internal factors, such as Financing to Deposit Ratio (FDR) and Non-Performing Financing (NPF), because of the presumption that these factors have the most significant influence on profit-sharing that exist in the Islamic banking system. This study aims to determine the effects of Financing to Deposit Ratio (FDR) and Non-Performing Financing (NPF) variables on Mudharabah Deposits of PT Bank Syariah Mandiri, both partially and simultaneously for the 2011-2017 period. The sample used in this study is PT Bank Syariah Mandiri in Indonesia by using multiple linear regression analysis which is processed using SPSS (Statistical Product Services and Solutions) software version 24. The results of this study state that FDR has a negative effect on profit sharing of Mudharabah Deposits, while NPF has a positive influence on the profit sharing of Mudharabah Deposits. These results also indicate that simultaneously the Financing to Deposit Ratio (FDR) and Non-Performing Financing (NPF) variables have a significant influence on the profit sharing of PT Bank Syariah Mandiri Mudharabah Deposits for the period 2011-2017. This is supported by the results of the coefficient of determination. The coefficient is 0.673 or $67.3 \%$ of profit sharing of the Mudharabah Deposits are influenced by the FDR and NPF variables, and the remaining $32.7 \%$ is influenced by other variables not used in this research model.
\end{abstract}

Keywords: Financing to Deposit Ratio (FDR), Non-Performing Financing (NPF), Profit Sharing of Mudharabah Deposit.

Abstrak: Seiring dengan semakin berkembangnya lembaga perbankan syariah di
Indonesia, maka semakin banyak pula macam bentuk jasa pelayanan yang disediakan
oleh lembaga perbankan syariah tersebut. Penelitian ini berfokus pada faktor-faktor
internal, seperti Financing to Deposit Ratio (FDR) dan Non Performing Financing
(NPF), karena adanya dugaan bahwa faktor-faktor tersebut memberikan pengaruh yang
paling signifikan pada keuntungan bagi hasil yang ada pada sistem perbankan syariah.
Penelitian ini bertujuan untuk menentukan pengaruh variabel Financing to Deposit Ratio
(FDR) dan Non-Performing Financing (NPF) terhadap bagi hasil Deposito Mudharabah
pada PT Bank Syariah Mandiri, baik secara parsial maupun simultan untuk periode 2011-
2017. Sampel yang digunakan dalam penelitian ini adalah PT Bank Syariah Mandiri di
Indonesia dengan menggunakan analisis regresi linier berganda (multiple regression 
analysis) yang diolah menggunakan software SPSS (Statistical Product Service and Solutions)versi 24. Hasil penelitian ini menyatakan bahwa FDR berpengaruh negatif terhadap bagi hasil DepositoMudharabah, sedangkan NPF memiliki pengaruh positif terhadap bagi hasil Deposito Mudharabah. Hasil tersebut juga mengindikasikan bahwa secara simultan variabel Financing to Deposit Ratio (FDR) dan Non-Performing Financing (NPF)memiliki pengaruh signifikan terhadap bagi hasil Deposito Mudharabah PT Bank Syariah Mandiri untuk periode 2011-2017. Hal ini didukung oleh hasil perhitungan koefisien determinasi sebesar 0.673 atau $67,3 \%$ bagi hasil Depositi Mudharabah dipengaruhi oleh variabel FDR dan NPF, dan sisanya sebesar 32,7\% dipengaruhi oleh variabel lain yang tidak digunakan di dalam model penelitian ini.

Article Info:

Received: October 1, $2018 \quad$ Accepted: November 28, $2018 \quad$ Available Online: December 13, 2018 DOI: http://dx.doi.org/10.30588/jmp.v8i1.391

\section{LATAR BELAKANG}

Sejak tahun 1992, terjadi perkembangan yang cukup signifikan pada perekonomian Islam di Indonesia yang diindikasikan dengan semakin banyaknya lembaga-lembaga keuangan syariah, khususnya dalam bidang perbankan syariah. Keberadaan lembagalembaga perbankan syariah ini telah disahkan oleh pemerintah melalui pemberlakuan Undang-Undang nomor 7 tahun 1992 tentang perbankan yang kemudian diubah dengan Undang-Undang nomor 10 tahun 1998. Kedua undang-undang tersebut menjelaskan bahwa lembaga perbankan dapat menjalankan aktifitas perbankan, baik secara konvensional atau pun syariah.

Isi kedua Undang-Undang itu sendiri menjelaskan bahwa bank diberikan kebebasan untuk menetapkan bentuk imbalan yang akan diterima oleh nasabah, yaitu bisa dalam bentuk bunga atau pun keuntungan bagi hasil. Kebebasan untuk menentukan tingkat bunga hingga 0 (nol) persen adalah kebijakan baru dalam pelaksanaan sistem perbankan secara umum. Pada tahun 2004, sebuah fatwa dikeluarkan oleh Majelis Ulama Indonesia (MUI) yang berkaitan dengan hukum bunga bank, yaitu Fatwa MUI nomor 1 tahun 2004. Fatwa tersebut dengan tegas menyatakan bahwa hukum pemberian bunga oleh lembaga keuangan adalah haram hukumnya. Berdasarkan hal itu, MUI berusaha menyadarkan masyarakat muslim di Indonesia agar berpindah dari bank konvensional dan lebih memilih bank syariah dalam hal jasa pengelolaan keuangan mereka.

Munculnya lembaga-lembaga perbankan syariah merupakan representasi dari keinginan untuk memenuhi niat para nasabah (khususnya yang beragama Islam) untuk menemukan sistem perbankan alternatif yang bisa membebaskan mereka dari riba atau bunga dengan dasar bagi hasil. Terkait dengan penerapan bunga, terdapat perbedaan prinsip antara bank konvensional dan bank syariah, yaitu sistem bunga yang diterapkan oleh bank konvensional ditiadakan oleh bank syariah. Namun, bank syariah menggunakan suatu sistem yang dinilai lebih adil dan tidak mengandung unsur riba, yaitu sistem bagi hasil (profit sharing). Animo masyarakat yang beragama Islam di Indonesia sangat positif, hal itu dapat dilihat dengan semakin maraknya lembaga-lembaga perbankan syariah yang berdiri. Dengan demikian, terjadi persaingan antara satu lembaga perbankan syariah dengan lembaga perbankan syariah lainnya. Salah satu cara yang 
dilakukan oleh lembaga perbankan syariah ini adalah upaya meningkatkan kualitas pelayanan yang tujuannya dapat menarik nasabah lebih banyak lagi.

Seiring dengan semakin berkembangnya lembaga perbankan syariah di Indonesia, maka semakin banyak pula macam bentuk jasa pelayanan yang disediakan oleh lembaga perbankan syariah tersebut. Beberapa penelitian menunjukkan adanya faktor-faktor yang dapat mempengaruhi nasabah untuk memilih lembaga perbankan syariah. Penelitian Erol dan El-Bdour (1998) di Jordan mengindikasikan orientasi masyarakat yang cenderung lebih kepada profit dan bukannya karena alasan nilai-nilai agama. Sementara itu, Nasrah (2008) yang mengutip penelitian Husnelly (2003) dan Mangkuto (2004), hal itu juga terjadi di Indonesia. Dari penelitian tersebut, Husnelly (2003) dan Mangkuto (2004) menunjukkan bahwa faktor bagi hasil merupakan pertimbangan yang paling mendasar bagi nasabah sebagai alasan untuk menempatkan dana atau menyimpan uangnya di lembaga perbankan syariah. Oleh karena itu, sangat penting bagi lembaga bank syariah untuk bisa meningkatkan dan juga mempertahankan kualitas yang sudah ada, khususnya dalam aspek pembagian hasil. Nasabah akan lebih cenderung membuat pertimbanganpertimbangan berdasarkan jumlah bagi hasil yang diterapkan oleh lembaga keuangan bank syariah yang nantinya akan diputuskan nasabah tersebut sebagai tempat ia berinvestasi.

Nasabah akan berpikir untuk berpindah ke lembaga bank syariah lain, jika tingkat bagi hasil yang diberikan terlalu rendah dan kemudian pada akhirnya memutuskan untuk berpindah menggunakan layanan bank syariah lainnya. Besaran tingkat bagi hasil sangat menentukan keberhasilan bank syariah untuk mengumpulkan dana dari pihak ketiga, khususnya karena karakteristik nasabah tersebut. Apriandika (2011) dalam penelitiannya menjelaskan pendapat Karsten (1982) bahwa jumlah bagi hasil yang diterima oleh nasabah bertumpu pada berhasil atau tidaknya pengelola dana dalam menghasilkan profit. Selanjutnya, tingkat laba bank syariah tidak saja berdampak pada besaran bagi hasil kepada para shareholders, tetapi juga berdampak pada jumlah bagi hasil yang akan diterima oleh nasabah yang telah mempercayakan pada bank syariah tersebut dalam menyimpan dananya. Konsep ini disebut sebagai Profit and Loss Sharing Concept.

Bank syariah dapat memberikan imbalan secara sukarela kepada pemilik dana dari hasil pengelolaan dana berdasarkan prinsip wadi'ah seperti giro wadi'ah, yaitu pemberian bagi hasil tidak boleh diperjanjikan sebelumnya. Sebaliknya, bank syariah dapat membagi keuntungan atas nisbah yang telah disepakati pada awal akad, seperti tabungan mudharabah dan deposito mudharabah berdasarkan pada prinsip mudharabah. Ada tiga kelompok masyarakat yang dibedakan dalam aspek pemilihan lembaga perbankan, seperti dijelaskan dalam kutipan yang diambil dari pernyataan Karim (2004), yaitu: syariah commited market, floating market, dan conventional market. Karim (2004) juga menjelaskan bahwa bank syariah lebih suka menerapkan sistem floating market pada sistem perbankannya.

Kelompok masyarakat yang disebut floating market ini adalah kelompok masyarakat yang memandang sistem perbankan tidak secara fanatik baik pada lembaga perbankan syariah dan juga lembaga perbankan konvensional. Namun, mereka lebih cenderung menempatkan dananya dengan dasar keuntungan yang akan didapatkan. Kecenderungan ini dapat dilihat dengan beberapa hasil penelitian yang menunjukkan alasan pemilihan bank syariah oleh nasabah yang dilakukan oleh Husnelly (2003) dan Mangkuto (2004) sebagaimana dikutip oleh Nasrah (2008). Hal yang menjadi bahan 
pertimbangan ketika melakukan investasi dana di dalam sebuah lembaga perbankan syariah adalah tingkat pendapatan bagi hasil. Demikian pula, Iqtishadia (2017) di dalam penelitiannya menunjukkan bahwa pasar terbesar bagi bank syariah saat sekarang ini adalah nasabah dari kelompok floating market yang menomorduakan aspek syariah atau pun konvensional, tetapi lebih mementingkan pertimbangan besaran pembagian financial benefit yang akan diterima.

Dari hasil penelitian-penelitian di atas, maka dapat dilihat bahwa penentuan profit akan menjadi faktor dan daya tarik yang sangat menentukan untuk mempengaruhi nasabah agar mau menyimpan dan menginvestasikan dananya pada bank tersebut. Imbalan yang diterima akan selalu menjadi bahan pertimbangan yang paling penting ketika melakukan investasi, khususnya pada kelompok floating market tersebut. Apabila tingkat profit yang akan diberikan dianggap menguntungkan, maka nasabah akan memilih menggunakan lembaga perbankan syariah sebagai tempat ia menyimpan dana, demikian pula sebaliknya. Jika tingkat profitnya rendah, maka ia akan cenderung memilih bank konvensional. Dengan demikian, dapat disimpulkan bahwa tingkat bagi hasil merupakan aspek yang bisa mempengaruhi dan menentukan berhasil atau tidaknya bank syariah mengumpulkan dana dari para nasabah.

Bank Syariah Mandiri beroperasi mulai tahun 1999 sebagai salah satu bank syariah terbaik di Indonesia dan turut melengkapi persaingan di industri keuangan dan perbankan syariah. Dari kinerja keuangan perusahaan dari tahun ke tahun, Bank Syariah Mandiri (BSM) mengalami perkembangan yang sangat pesat. Pada tahun 2014, laba BSM tercatat mencapai Rp72 miliar (Antonio dkk., 2006). Bank Syariah Mandiri mengalami penurunan laba yang cukup dalam pada tahun 2014, jika dibandingkan posisi laba tahun 2013 sebesar Rp651 miliar. Dana Pihak Ketiga (DPK) yang berhasil dihimpun mengalami pertumbuhan sebesar 6,95\% atau tumbuh sebesar Rp3,8 triliun. Pada sisi pembiayaan berbasis bagi hasil, BSM justru mengalami penurunan sebesar $3,86 \%$. Penurunan ini disebabkan oleh penurunan drastis pada pembiayaan musyarakah yang disalurkan. Selain DPK, faktor lain yang memiliki kaitan erat dengan penyaluran pembiayaan berbasis bagi hasil adalah tingkat bagi hasil. Hasil penelitian Antonio dkk. (2006) menjelaskan bahwa ada pengaruh yang disebabkan oleh besarnya tingkat bagi hasil terhadap pembiayaan mudharabah pada bank umum syariah.

Faktor internal merupakan salah satu faktor yang bisa memberikan pengaruh pada tingkat bagi hasil yang akan dterima oleh nasabah. Dari uraian di atas, penelitian ini akan berfokus pada faktor-faktor internal, seperti Financing to Deposit Ratio (FDR) dan Non Performing Financing (NPF), karena adanya dugaan bahwa faktor-faktor tersebut memberikan pengaruh yang paling signifikan pada keuntungan bagi hasil yang ada pada sistem perbankan syariah. Financing to Deposit Ratio (FDR) adalah faktor pertama yang akan diukur untuk mengetahui pengaruh tingkat bagi hasil. FDR disebut juga sebagai Loan to Deposit Ratio (LDR) yang merupakan besaran rasio nilai kredit dari dana yang diperoleh bank. Istilah FDR dalam bank syariah diartikan sebagai rasio antara total financing yang didistribusikan berasal dari dana pihak ketiga yang telah dikumpulkan. Kemampuan bank untuk memperoleh bayaran atau dana kembali dinyatakan dalam FDR, yaitu deposan bertumpu pada kredit yang akan diperolehnya. Atau kemampuan bank untuk melakukan pengimbangan pada pembiayaan dan juga kewajibannya untuk memenuhi ketentuan dari deposan yang ingin menarik dananya tersebut. Tingkat rasio yang tinggi mengindikasikan bahwa lembaga perbankan tersebut berhasil menjalankan fungsi intermediasi, baik sebagai penghimpun maupun pengalokasi dana. 
Tabel 1. Perkembangan Financing Deposit Ratio (FDR) Bank Syariah Mandiri Tahun 2011-2017

\begin{tabular}{ccccc}
\hline \multirow{2}{*}{ Tahun } & \multicolumn{5}{c}{ Triwulan } \\
\cline { 2 - 5 } & I & II & III & IV \\
\hline 2011 & $84.06 \%$ & $88.52 \%$ & $89.86 \%$ & $86.03 \%$ \\
\hline 2012 & $87.25 \%$ & $92.21 \%$ & $93.90 \%$ & $94.40 \%$ \\
\hline 2013 & $95.61 \%$ & $94.22 \%$ & $91.29 \%$ & $89.37 \%$ \\
\hline 2014 & $90.34 \%$ & $89.91 \%$ & $85.68 \%$ & $82.13 \%$ \\
\hline 2015 & $81.45 \%$ & $85.01 \%$ & $84.49 \%$ & $81.99 \%$ \\
\hline 2016 & $80.16 \%$ & $82.31 \%$ & $80.40 \%$ & $79.19 \%$ \\
\hline 2017 & $77.75 \%$ & $80.03 \%$ & $78.29 \%$ & $77.66 \%$ \\
\hline
\end{tabular}

Sumber: Laporan Keuangan Bank Syariah Mandiri Triwulan IV Tahun 2011-2017 yang diolah menggunakan SPSS versi 24.

Pada Tabel 1 di atas, rata-rata Financing Deposit Ratio (FDR) pada tahun 2011 Triwulan I sampai dngan tahun 2012 Triwulan IV mengalami kenaikan dari 84,06\% menjadi 94,40\%. Namun, pada tahun 2013 tepatnya pada triwulan I terjadi penurunan hingga tahun 2014 triwulan IV dari 95,61\% menurun menjadi 82,13\%. Selanjutnya, terjadi penurunan kembali ke 77,66\% pada tahun 2017 triwulan IV. Artinya, simpanan dana yang dikumpulkan dari masyarakat masih sebagian yang disalurkan dalam bentuk pembiayaan dan belum secara keseluruhan terdistribusi.

Selain itu, faktor yang dapat mempengaruhi tingkat bagi hasil dari Deposito Mudharabah adalah Non-Performing Financing (NPF) yang didefinisikan sebagai jumlah keseluruhan pembiayaan bermasalah dengan total pembiayaan yang disalurkan kepada masyarakat. Jika bank mengalami kendala dalam hal menagih kembali pinjaman dana kepada penerima, maka bank tersebut akan mengalami NPF. Hal ini dapat terjadi karena disengaja, tetapi juga bisa terjadi karena hal-hal lain yang tidak bisa dikendalikan atau diatasi oleh pihak yang meminjam dana. Ukuran NPF merepresentasikan performa kerja suatu bank, baik dalam mengelola maupun menyalurkan dana. Jika NPF kecil, maka risiko kredit yang akan ditanggung pihak bank juga akan semakin kecil (Nusantara, 2009). Sebaliknya, jika pembiayaan mempunyai porsi yang semakin besar, hal tersebut akan menyebabkan penurunan return atau pendapatan yang diperoleh (Ali, 2004).

Berdasarkan Tabel 2 berikut, terjadi peningkatan cukup signifikan pada tingkat NPF pada tahun 2011 triwulan I hingga tahun 2015 triwulan IV yang sangat signifikan, yaitu dari $1,12 \%$ hingga 4,05\%. Namun, pada tahun 2016 triwulan I NPF mengalami penurunan, yaitu menjadi 4,32\% sampai dengan tahun 2017 triwulan IV menurun sampai dengan 2,71\%. Bank Indonesia telah menetapkan batas aman NPF sebesar 5\%. 
Tabel 2. Perkembangan Non-Performing Financing (NPF) Bank Syariah Mandiri Tahun 2011-2017

\begin{tabular}{ccccc}
\hline \multirow{2}{*}{ Tahun } & \multicolumn{5}{c}{ Triwulan } \\
\cline { 2 - 5 } & I & II & III & IV \\
\hline 2011 & $1.12 \%$ & $1.14 \%$ & $1.26 \%$ & $0.95 \%$ \\
\hline 2012 & $0.86 \%$ & $1.41 \%$ & $1.55 \%$ & $1.14 \%$ \\
\hline 2013 & $1.55 \%$ & $1.10 \%$ & $1.59 \%$ & $2.29 \%$ \\
\hline 2014 & $2.65 \%$ & $3.90 \%$ & $4.23 \%$ & $4.29 \%$ \\
\hline 2015 & $4.41 \%$ & $4.70 \%$ & $4.34 \%$ & $4.05 \%$ \\
\hline 2016 & $4.32 \%$ & $3.74 \%$ & $3.63 \%$ & $3.13 \%$ \\
\hline 2017 & $3.16 \%$ & $3.23 \%$ & $3.12 \%$ & $2.71 \%$ \\
\hline
\end{tabular}

Sumber: Laporan Keuangan Bank Syariah Mandiri Triwulan IV Tahun 2011-2017 yang diolah menggunakan SPSS versi 24.

\section{KAJIAN TEORITIS}

\section{Pengertian Bank Syariah}

Bank syariah merupakan lembaga keuangan yang sifatnya sebagai intermediari atau perantara suatu pihak dengan dana yang berlebih kepada pihak yang membutuhkan dana untuk melakukan atau mendirikan usaha berdasarkan hukum Islam. Peran lain yang dimiliki oleh bank syariah adalah pengelola investasi dari pihak ketiga dan juga sebagai investor atau pengelola dana sendiri. Pengoperasian bank syariah adalah tidak menerapkan sistem bunga kepada pinjaman atau simpanan nasabah. Bank syariah bisa juga disebut sebagai non-interest bank atau lembaga keuangan yang sistem pengoperasiannya dilandasi oleh Al Qur'an dan Hadist Nabi SAW. Selain itu, bank syariah dengan dasar prinsip-prinsip syariah merupakan lembaga keuangan yang melayani berbagai jenis jasa termasuk pembiayaan dan jasa keuangan lainnya dengan peredaran uang dan lalu lintas pembayaran.

Hukum Islam adalah landasan pelaksanaan kerja bank syariah, yaitu bank tidak akan mengenakan maupun memberikan bunga sebagai imbalan. Namun, nasabah akan menerima imbalan tergantung pada akad dan juga perjanjian antara pihak bank dan nasabah, sedangkan perjanjian atau akad pada bank syariah berlandaskan pada syarat dan rukun yang sesuai syariah Islam. Bank syariah merupakan bank yang aturan dan perjanjiannya dibuat atas dasar hukum Islam, baik dalam hal menyimpan dana dan atau pembayaran kegiatan usaha kepada pihak lain atau kegiatan lainnya. Sementara itu dari sisi investasi, bank syariah juga melakukan investasi menurut prinsip-prinsip syariah dengan tujuan penempatan investasi untuk kesejahteraan umat, membantu pembangunan ekonomi, dan pengembangan aspek sosial masyarakat. Berdasarkan pengertianpengertian ini, maka bank syariah merupakan bank yang mempunyai berbagai peranan, baik sebagai perantara maupun lembaga investasi yang tidak menerapkan sistem bunga, tetapi lebih pada asas asal syariah. Bank syariah tidak akan memberikan imbalan berupa bunga, tetapi imbalan tersebut akan disesuaikan dengan perjanjian yang sudah dibuat sebelumnya berdasarkan prinsip-prinsip syariah. 


\section{Financing to Deposit Ratio (FDR)}

Kasmir (2007) menjelaskan dalam bukunya bahwa indikator untuk mengetahui likuid atau tidaknya sebuah bank dapat ditinjau berdasarkan besaran rasio Financing to Deposit Ratio (FDR) bank tersebut. FDR sebenarnya sama dengan Loan to Deposit Ratio (LDR) di bank konvensional. Penyebutan yang berbeda ini disebabkan karena pada lembaga perbankan syariah tidak menggunakan loan atau pinjaman, tetapi lebih menggunakan istilah financing atau pembiayaan. Likuid atau tidaknya sebuah bank, jika semua liabilitas hutang sudah terpenuhi dan permintaan dana nasabah bisa langsung disetujui tanpa ada penundaan.

Loan to Deposit Ratio (LDR) merupakan rasio untuk mengukur komposisi jumlah kredit yang diberikan dibandingkan dengan jumlah dana masyarakat dan modal sendiri yang digunakan. Rumus untuk mendapatkan Loan to Deposit Ratio adalah:

$$
\text { Loan to Deposit Ratio }=\frac{\text { total loans }}{\text { total deposit }+ \text { equity }} \times 100 \%
$$

Di sisi lain, Financing to Deposit Ratio (FDR) adalah perbandingan antara jumlah pembiayaan yang disalurkan bank syariah dengan Dana Pihak Ketiga yang didapat oleh bank. FDR ini dapat mengindikasikan kemampuan yang ada pada bank untuk menggunakan dana pihak ketiga dan disalurkan kepada pemohon dan juga kemampuan bank memperoleh dana yang dipinjam untuk dikembalikan kepada deposan berdasarkan kredit yang berperan sebagai sumber likuiditas. Jika jumlah kredit semakin besar, maka return yang didapatkan bank juga akan semakin bertambah, karena penambahan return otomatis akan meningkatkan laba. Rumus rasio likuiditas Financing to Deposit Ratio $(F D R)$ adalah:

$$
\text { Financing to Deposit Ratio }=\frac{\text { total pembiayaan }}{\text { jumlah dana yang diterimahank }}
$$

Untuk mengukur rasio likuiditas, penulis menggunakan Financing to Deposit Ratio (FDR) yang membandingkan jumlah dana yang diberikan dan dana yang dikumpulkan termasuk giro, deposito, dan tabungan. Jika nilai kredit semakin besar, maka return akan besar, karena otomatis pendapatan juga akan mengalami peningkatan.

\section{Non-Performing Financing (NPF)}

Non-Performing Financing (NPF) dijelaskan oleh Nugraha (2014:25) sebagai suatu pembiayaan yang mempunyai masalah, karena pelaksanaan pembiayaan tersebut tidak atau belum mencapai sasaran yang diharapkan oleh bank. Faktor yang bisa mempengaruhi NPF, salah satunya adalah ketepatan waktu pembayaran oleh nasabah, sehingga hal tersebut dapat menurunkan potensi terjadinya masalah dalam pembayaran dan penyaluran dana. Kemampuan bank untuk melakukan penyaluran dana dengan baik, termasuk juga melakukan pemantauan dapat menekan tingkat NPF menjadi seminimal 
mungkin. Dengan demikian, perlu dilakukan penilaian terhadap kemungkinan terjadinya penyimpangan pembiayaan oleh nasabah dan juga indikasi kegagalan untuk membayar pinjaman oleh nasabah. Dari uraian ini, dapat disimpulkan bahwa NPF yang tinggi akan menyebabkan masalah bagi bank, karena akan mengalami kerugian. NPF dapat dirumuskan sebagai berikut:

$$
\text { Non }- \text { Performance Financing }=\frac{\text { Jumlah pembiayaan bermasalah }}{\text { total pembiayaan }} \times 100 \%
$$

\section{Pengertian Bagi Hasil}

Prinsip bagi hasil adalah pembagian hasil usaha pihak nasabah dan pihak bank syariah yang telah membuat perjanjian sebelumnya. Hasil usaha yang diterima oleh kedua belah pihak nantinya akan dibagi menurut porsi atau bagian masing-masing sesuai dengan perjanjian yang ditetapkan dengan nisbah. Pengertian nisbah adalah persentase atau jumlah bagian yang disepakati oleh pihak nasabah dan pihak bank ketika melakukan kerjasama. Hasil usaha akan didistribusikan dengan prinsip yang telah ditentukan oleh MUI yang berlaku khusus bagi bank syariah atau lembaga syariah non-bank. Dewan Syariah Nasional di dalam fatwanya nomor 14/DSN-MUI/IX/2000 berkaitan dengan sistem penyaluran hasil usaha pada perbankan syariah untuk mencatat hasil usahanya menggunakan ketentuan-ketentuan sebagai berikut:

a. Pada prinsipnya, Lembaga Keuangan Syariah (LKS) boleh menggunakan sistem Accrual Basis maupun Cash Basis dalam administrasi keuangannya.

b. Dilihat dari sisi kemaslahatan (al-ashlah), di dalam pencatatan sebaiknya digunakan sistem Accrual Basis; akan tetapi dalam distribusi hasil usaha hendaknya ditentukan atas dasar penerimaan yang benar-benar terjadi (Cash Basis).

c. Penetapan sistem yang dipilih harus disepakati dalam akad.

Penjelasan tersebut didukung oleh fatwa Dewan Syariah Nasional nomor 15/DSNMUI/IX/2000 berkaitan dengan Prinsip Distribusi Hasil Usaha dalam Lembaga Keuangan Syariah dengan ketentuan berikut ini:

a. Pada dasarnya, LKS boleh menggunakan prinsip bagi hasil (Net Revenue Sharing) maupun bagi untung (Profit Sharing) dalam pembagian hasil usaha dengan mitra (nasabah)-nya.

b. Dilihat dari segi kemaslahatan (al-ashlah), saat ini pembagian hasil usaha sebaiknya digunakan prinsip bagi hasil (Net Revenue Sharing).

c. Penerapan prinsip pembagian hasil usaha yang dipilih harus disepakati dalam akad.

Menurut isi fatwa-fatwa tersebut menunjukan bahwa hasil usaha pada lembaga keuangan syariah akan dibagi dengan menerapkan asas Revenue Sharing serta asas Profit and Loss Sharing atau bagi hasil. Sementara itu, dasar perhitungannya dengan Revenue Sharing adalah jumlah penjualan dan pendapatan bruto dari usaha yang dikurangi biaya sebelumnya. Nisbah yang telah disepakati dikalikan dengan pendapatan kotor, maka akan 
didapatkan porsi pembagian hasil dalam Revenue Sharing, baik untuk pihak peminjam maupun pihak bank [Nisbah x Laba Kotor].

Sementara itu, pembagian hasil dengan asal Profit/Loss Sharing akan diperoleh dengan menghitung Laba/Rugi usaha. Nasabah dan pihak bank akan mendapatkan laba atas hasil usaha Mudharib, tetapi jika usaha mengalami kerugian maka kedua pihak akan sama-sama menanggungnya. Cara penghitungannya adalah persentase nisbah dikalikan laba usaha sebelum pajak, maka akan diperoleh hasil yang bisa dibagi rata sesuai perjanjian yang telah dibuat.

\section{Deposito Mudharabah}

Menurut Al Arif (2010:35), definisi deposito ialah satu jenis metode penyimpanan dana oleh nasabah dengan ketentuan jumlah minimal, ketentuan jangka waktu, dan perolehan imbalan yang lebih tinggi dibandingkan dengan simpanan atau tabungan biasa. Deposito bisa dibuka dengan mengikuti aturan jumlah dan jangka waktu tertentu dan disepakati oleh nasabah, sehingga dana yang ada di dalam deposito belum bisa dicairkan jika belum jatuh tempo. Metode penyimpanan dana dengan deposito ini lebih disukai oleh nasabah yang mempunyai dana dalam jumlah besar dan tidak digunakan, karena tujuan pembukaan deposito adalah simpanan dan sarana investasi.

Sementara itu, menurut Undang-Undang nomor 10 Tahun 1988, pengertian deposito adalah penyimpanan dana yang penarikannya hanya bisa dilakukan pada waktu yang telah disepakati oleh nasabah atau pada waktu jatuh tempo. Jangka waktu deposito biasanya telah ditentukan oleh bank, sedangkan pada bank syariah investasi deposito bisa dilakukan untuk surat-surat berharga dengan menggunakan prinsip Mudharabah. Anshori (2007:94) menjelaskan bahwa bank dan nasabah, keduanya akan memperoleh keuntungan. Untuk bank penyimpanan dana, keuntungan nasabah deposito adalah waktu penyimpanan yang biasanya lebih lama akan bisa digunakan secara lebih efisien dan membuat bank bisa menyalurkan dana untuk berbagai macam kegiatan usaha yang produktif. Sementara, pada sisi nasabah, ia akan memperoleh keuntungan bagi hasil berdasarkan nisbah yang sudah disetujui sejak pembukaan deposito di lembaga perbankan tersebut.

Karim (2004:303) menjelaskan pengertian deposito syariah sebagai deposito yang dilakukan dengan berlandaskan asas-asas syariah. Deposito yang diterapkan pada lembaga perbankan syariah dan lembaga keuangan syariah adalah Deposito Mudharabah berdasarkan fatwa Dewan Syariah Nasional MUI. Istilah Mudharabah berasal dari kata dharb yang berarti memukul atau berjalan. Pengertian memukul atau berjalan ini lebih tepatnya adalah proses seseorang memukulkan kakinya dalam menjalankan usahanya. Sementara itu, Ismail (2015:60) menjelaskan pengertian Mudharabah sebagai perjanjian bagi hasil ketika pemilik dana/modal (pemodal), biasa disebut shahibul maal, menyediakan modal (100\%) kepada penguasa sebagai pengelola, yang biasa disebut mudharib, untuk melakukan aktivitas produktif dengan syarat keuntungan yang dihasilkan akan dibagi di antara mereka menurut kesepakatan yang ditentukan sebelumnya dalam akad. Shahibul maal (pemodal) adalah pihak yang memiliki modal, tetapi tidak berbisnis, dan mudharib (pengelola atau entrepreneur) adalah pihak yang menjalankan bisnis, tetapi tdak memiliki modal. 
Menurut Ismail (2011:8), Mudharabah berarti bahwa salah satu pihak menyediakan modal dan pihak lain memanfaatkannya untuk tujuan-tujuan usaha berdasarkan kesepakatan bahwa keuntungan dari usaha tersebut akan dibagi menurut bagian yang ditentukan. Jika usaha mengalami kerugian, bukan disebabkan karena lalai atau pun tindakan curang oleh pengelola dana, maka kerugian itu akan ditanggung oleh pemilik modal sepenuhnya. Apabila terjadi kerugian karena kelalaian pengelola, maka pengelola bertanggung jawab sepenuhnya. Mudharib tidak ikut menyerahkan modal, tetapi menyerahkan tenaga dan keahliannya dan tidak meminta gaji atau upah dalam menjalankan usahanya. Pemilik dana hanya menyediakan dana dan tidak dibenarkan untuk ikut campur dalam manajemen usaha yang dibiayainya. Kesediaan pemilik dana untuk menanggung risiko apabila terjadi kerugian menjadi dasar untuk mendapatkan bagian dari keuntungan. Berdasarkan pengertian-pengertian yang telah dituliskan tersebut di atas, maka Deposito Mudharabah adalah dana investasi yang sifatnya sesuai dengan syari'at Islam dari nasabah yang penarikannya dilakukan pada waktu tertentu sesuai dengan kesepakatan. Pemilik rekening disebut deposan yang berasal dari perorangan atau badan.

\section{METODE PENELITIAN}

Analisis diskriptif adalah suatu metode penelitian yang dilakukan dengan membuat diskripsi atau gambaran obyek penelitian yang direpresentasikan dengan data sampel sebagaimana adanya, tidak dilakukan analisis dan hanya menarik kesimpulan secara umum (Muhammad, 2014). Pada bagian ini, penulis akan menguraikan data yang berhasil dikumpulkan. Data tersebut berupa Financing to Deposit Ratio (FDR) dan NonPerforming Finance (NPF) yang termasuk dalam variabel independen. Data yang telah terkumpul kemudian diolah untuk mengetahui apakah variabel data FDR dan NPF mempengaruhi secara signifikan terhadap bagi hasil Deposito Mudharabah pada Bank Syariah Mandiri periode 2011-2017. Berdasarkan hasil analisis statistik diskriptif, Tabel 3 menunjukkan karakteristik sampel yang digunakan dalam penelitian ini meliputi jumlah sampel $(\mathrm{N})$, nilai minimum, nilai maksimum, rata-rata sampel (mean), dan standar deviasi $(\sigma)$ untuk masing-masing variabel.

Tabel 3. Uji Diskriptif

Descriptive Statistics

\begin{tabular}{lcccccc}
\hline & N & Minimum & Maximum & Mean & Std. Deviation \\
\hline $\begin{array}{l}\text { BAGI HASIL DEPOSITO } \\
\text { MUDHARABAH }\end{array}$ & 28 & 17066230,00 & 37547789,00 & 27362613,8900 & 6038272,78200 \\
\hline FDR & 28 & 77,66 & 95,61 & 85,8396 & 5,59119 \\
\hline NPF & 28 &, 86 & 4,70 & 2,6989 & 1,32395 \\
\hline Valid N (listwise) & 28 & & & & \\
\hline
\end{tabular}

Berdasarkan Tabel 3, nilai mean variabel FDR sebesar 85,8396 dengan nilai standar deviasi sebesar 5,59119. Nilai minimum variabel FDR sebesar 77,66 diperoleh dari Bank Syariah Mandiri pada triwulan IV tahun 2017, sedangkan nilai maksimum sebesar 95,61 diperoleh dari Bank Syariah Mandiri pada tiwulan I tahun 2013. Nilai mean untuk variabel NPF sebesar 2,6989 dengan nilai standar deviasi sebesar 1,32395. Nilai minimum untuk variabel NPF sebesar 0,86 diperoleh dari Bank Syariah Mandiri pada triwulan I tahun 2012. sedangkan nilai maksimum sebesar 4,70 diperoleh dari Bank 
Syariah Mandiri pada triwulan II tahun 2015. Untuk bagi hasil Deposito Mudharabah mempunyai nilai mean sebesar 27362613,8900 dengan standar deviasi sebesar 6038272,78200. Nilai minimum untuk bagi hasil Deposito Mudharabah sebesar 17066230,00 diperoleh dari Bank Syariah Mandiri pada triwulan I tahun 2011, sedangkan nilai maksimum sebesar 37547789,00 diperoleh dari Bank Syariah Mandiri pada triwulan IV tahun 2017.

\section{Uji Multikolinearitas}

Uji multikolinearitas merupakan kondisi ketika dua atau lebih variabel bebas saling berkolerasi. Munculnya multikolineritas dapat diidentifikasikan dari nilai VIF (Variance Inflation Factor) yang merupakan simpangan baku kuadrat dan digunakan untuk mengukur keeratan hubungan antarvariabel bebas. Beberapa hal yang dapat menjadi dasar untuk mengetahui keberadaan multikolinearitas pada model regresi dengan memperhatikan: jika nilai VIF tidak lebih dari 10 (VIF $\leq 10$ ), maka model regresi bebas dari multikolineritas. Nilai tolerance tidak kurang dari 0,1 (tolerance $\geq 0,10$ ), maka model regresi bebas dari multikolinearitas.

Tabel 4. Uji Multikolinearitas

\begin{tabular}{clll}
\multicolumn{3}{c}{ Model } & \multicolumn{2}{c}{ Coefficients $^{\mathbf{a}}$} \\
\cline { 3 - 4 } & & \multicolumn{2}{c}{ Collinearity $^{\text {Statistics }}$} \\
\cline { 3 - 4 } 1 & & Tolerance & VIF \\
\cline { 3 - 4 } & FDR &, 628 & 1,593 \\
\cline { 2 - 4 } a. Dependent Variable: & BAGI HASIL DEPOSITO MUDHARABAH
\end{tabular}

a. Dependent Variable: BAGI HASIL DEPOSITO MUDHARABAH

Berdasarkan Tabel 4, perolehan nilai VIF dan Tolerance yang dihasilkan variabel FDR adalah 1,593 dan 0,628, sedangkan untuk variabel NPF sebesar 1,593 dan 0,628. Oleh karena itu, hasil tersebut menunjukkan tidak terdapat multikolinearitas pada model regresi ini dengan dasar tidak adanya nilai Tolerance pada semua variabel independen yang kurang dari 0,10 dan tidak ada nilai Variance Inflation Factor (VIF) yang lebih dari 10 pada kelima variabel.

\section{Uji Autokorelasi}

Autokorelasi yang tidak ditemukan di dalam suatu regresi menunjukkan bahwa persamaan regresi tersebut baik. Jika terjadi autokorelasi, maka persamaan regresi menjadi tidak baik atau tidak layak diprediksi. Uji Durbin-Watson (DW) digunakan untuk mengukur keberadaan autokorelasi pada suatu persamaan regresi dengan ketentuan seperti di bawah ini:

a. Terjadi autokorelasi positif jika nilai DW di bawah -2 (DW $<-2)$.

b. Tidak terjadi autokorelasi jika nilai DW berada di antara -2 dan +2 atau $-2<\mathrm{DW}<+2$.

c. Terjadi autokorelasi negatif jika nilai DW di atas +2 atau DW $>+2$. 


\section{Tabel 5. Uji Autokorelasi}

Model Summary ${ }^{\mathrm{b}}$

\begin{tabular}{l|c|cc|c|c}
\hline Model & $\mathbf{R}$ & R Square & $\begin{array}{c}\text { Adjusted } \mathbf{R} \\
\text { Square }\end{array}$ & $\begin{array}{c}\text { Std. Error of the } \\
\text { Estimate }\end{array}$ & Durbin-Watson \\
\hline 1 &, $835^{\mathrm{a}}$ &, 697 &, 673 & 3452327,79500 &, 384 \\
\hline
\end{tabular}

a. Predictors: (Constant), NPF, FDR

b. Dependent Variable: BAGI HASIL DEPOSITO MUDHARABAH

Dari hasil di atas, dapat dilihat bahwa nilai DW adalah 0,384 , maka tidak terjadi autokorelasi karena DW berada di antara -2 dan +2 atau $-2<\mathrm{DW}<+2$. Apabila kriteria pengambilan keputusan menggunakan dl dan du pada tabel DW, maka Nilai DurbinWatson sebesar 0,384, kemudian nilai ini dibandingkan dengan nilai tabel DW dengan menggunakan nilai signifikansi 5\%, jumlah sampel 28 (n) dan jumlah variabel independen $2(\mathrm{k}=2)$ dan didapatkan nilai dl (batas luar)=1,2553; du (batas dalam)=1,5596. Karena nilai DW 0,504 berada di antara dl dan du $(\mathrm{dl}<\mathrm{DW}<\mathrm{du})$, maka Ho diterima yangberarti tidak terjadi autokorelasi.

\section{HASIL DAN PEMBAHASAN}

\section{Uji Hipotesis}

Pada dasarnya, uji hipotesis merupakan proporsi atau tanggapan yang sering digunakan sebagai dasar pembuatan keputusan/solusi persoalan dan juga untuk dasar penelitian lebih lanjut. Uji hipotesis dilakukan untuk mengetahui pengaruh FDR dan NPF terhadap bagi hasil Deposito Mudharabah. Pengujian ini menggunakan uji t dan uji $\mathrm{F}$ sebagai berikut:

\section{Uji Parsial (Uji t)}

Uji t merupakan uji statistik yang seringkali ditemui dalam masalah-masalah praktis statistika. Uji t menunjukkan seberapa jauh pengaruh satu variabel independen secara individual dalam menerangkan variabel dependen. Tabel 6 menyajikan hasil uji t.

Table 6. Uji t

Coefficients $^{\mathrm{a}}$

\begin{tabular}{|c|c|c|c|c|c|c|}
\hline & \multirow[t]{2}{*}{ Model } & \multicolumn{2}{|c|}{ Unstandardized Coefficients } & \multirow{2}{*}{$\begin{array}{c}\begin{array}{c}\text { Standardized } \\
\text { Coefficients }\end{array} \\
\text { Beta }\end{array}$} & \multirow[t]{2}{*}{$\mathbf{t}$} & \multirow[t]{2}{*}{ Sig. } \\
\hline & & B & Std. Error & & & \\
\hline \multirow[t]{3}{*}{1} & (Constant) & 76448394,450 & 14000321,290 & & 5,460 &, 000 \\
\hline & FDR & $-621757,316$ & 150000,695 &,- 576 & $-4,145$ &, 000 \\
\hline & $\mathrm{NPF}$ & 1587906,174 & 633468,395 & ,348 & 2,507 & 019 \\
\hline
\end{tabular}

a. Dependent Variable: BAGI HASIL DEPOSITO MUDHARABAH

Apabila $t_{\text {hitung }}>\mathrm{t}_{\text {tabel }}$, berarti $\mathrm{H}_{0}$ ditolak dan $\mathrm{H}_{1}$ diterima, artinya variabel bebas $(\mathrm{X})$ secara parsial mempunyai hubungan yang signifikan terhadap variabel terikat (Y). Begitu pun sebaliknya, apabila $\mathrm{t}_{\text {hitung }}<\mathrm{t}_{\text {tabel }}$, berarti $\mathrm{H}_{0}$ diterima dan $\mathrm{H}_{1}$ ditolak, artinya tidak ada pengaruh antara variabel bebas terhadap variabel terikat. Dengan menggunakan tingkat keyakinan $95 \%$ atau $\alpha=0,05$ dan 28 data, maka dapat 
dihasilkan $t_{\text {tabel }}$ sebesar 1,70113 . Berikut interprestasi pengujian hipotesis variabel independen terhadap variabel dependen melalui uji t pada penelitian ini:

\section{Pengaruh Financing To Deposit Ratio terhadap Bagi Hasil Deposito Mudharabah}

Berdasarkan Tabel 6 diketahui tabel dari variabel Financing to Deposit Ratio sebesar $-4,145$ dengan tingkat signifikansi $0,000<0,05$ artinya Ho diterima dan $\mathrm{H}_{1}$ ditolak. Karena nilai thitung $-4,145$ lebih kecil daripada $t_{\text {tabel }}$ atau $-4,145<1,70113$ maka dapat disimpulkan bahwa FDR memiliki pengaruh terhadap bagi hasil Deposito Mudharabah. Sementara, nilai FDR menunjukkan angka negatif yang artinya FDR berpengaruh negatif terhadap bagi hasil Deposito Mudharabah.

\section{Pengaruh Non-Performing Financing terhadap Bagi Hasil Deposito Mudharabah}

Berdasarkan Tabel 6 diketahui tabel dari variabel Non-Performing Financing sebesar 2,507 dengan tingkat signifikansi $0,019<0,05$ artinya Ho ditolak dan $\mathrm{H}_{1}$ diterima. Karena nilai $t_{\text {hitung }} 2,507$ lebih besar daripada $t_{\text {tabel }}$ atau 2,507>1,70113 maka dapat disimpulkan bahwa NPF memiliki pengaruh tehadap bagi hasil Deposito Mudharabah. Sementara, nilai NPF menunjukkan angka positif yang artinya NPF berpengaruh positif terhadap bagi hasil Deposito Mudharabah.

Hasil uji t di atas menunjukkan bahwa dari kedua variabel independen, FDR berpengaruh negatif terhadap variabel dependen, sedangkan NPF berpengaruh positif terhadap variabel dependen.

\section{Uji Simultan (Uji F)}

Penelitian ini menggunakan uji $\mathrm{F}$ atau uji koefisien regresi secara serentak, yaitu pengujian untuk mengetahui pengaruh variabel independen secara serentak terhadap variabel dependen, apakah memiliki pengaruh signifikan atau tidak. Dalam pengujian ini ditentukan taraf signifikansinya menggunakan 0,05 dengan menggunakan nilai $\mathrm{F}_{\text {tabel }}$ dengan jumlah sampel $(\mathrm{n})=28$; jumlah variabel $(\mathrm{k})=2$; df $1=\mathrm{k}-1$ atau 3-1=2 dan df $2=\mathrm{n}-\mathrm{k}$ atau $28-3=25$ ( $\mathrm{k}$ adalah jumlah variabel), maka diperoleh $\mathrm{F}_{\text {tabel }}$ adalah 3,39.

\section{Tabel 7. Uji F}

\begin{tabular}{lllr|rrrr}
\hline \multicolumn{8}{c}{ ANOVA $^{\mathbf{a}}$} \\
\hline \multirow{2}{*}{1} & Model & Sum of Squares & Df & Mean Square & \multicolumn{1}{c}{ F } & Sig. \\
\cline { 2 - 7 } & Regression & 686475751100000,000 & 2 & 343237875500000,000 & 28,799 &, $000^{\mathrm{b}}$ \\
\cline { 2 - 7 } & Residual & 297964180000000,000 & 25 & 11918567200000,000 & & \\
\hline
\end{tabular}

a. Dependent Variable: BAGI HASIL DEPOSITO MUDHARABAH

b. Predictors: (Constant), NPF, FDR

Dari Tabel 7, nilai $\mathrm{F}_{\text {hitung }}$ untuk model regresi yang diperoleh sebesar 28,799 dengan nilai signifikansi sebesar 0,000 , nilai dari Tabel $\mathrm{F}$ diperoleh dengan $\mathrm{df}_{1}=2$ dan $\mathrm{df}_{2}=25$ sebesar 3,39. Hasil uji pengaruh FDR dan NPF diperoleh hasil $F_{\text {hitung }}(28,799)>F_{\text {tabel }}$ $(3,39)$. Hasil tersebut mengindikasikan bahwa secara simultan atau bersama-sama, 
Financing to Deposit Ratio (FDR) dan Non-Performing Financing (NPF) berpengaruh secara signifikan terhadap bagi hasil Deposito Mudharabah.

\section{Koefisien Determinasi $\left(\mathbf{R}^{2}\right)$}

Koefisien determinasi adalah nilai yang menunjukkan seberapa besar variabel independen dapat menjelaskan variabel dependennya. Tabel 8 menunjukkan hasil koefisien determinasi dalam penelitian ini.

Table 8. Koefisien Determinasi $\left(\mathbf{R}^{2}\right)$

Model Summary

\begin{tabular}{cr|r|rrr|r}
\hline Model & $\mathbf{R}$ & $\mathbf{R}$ Square & Adjusted $\mathbf{R}$ Square & $\begin{array}{c}\text { Std. Error of the } \\
\text { Estimate }\end{array}$ & \multicolumn{2}{c}{ Durbin-Watson } \\
\hline 1 &, $835^{\mathrm{a}}$ &, 697 &, 673 & 3452327,79500 &, 384 \\
\hline
\end{tabular}

a. Predictors: (Constant), NPF, FDR

b. Dependent Variable: BAGI HASIL DEPOSITO MUDHARABAH

Berdasarkan Table 8, hasil analisis yang didapatkan dari koefisien korelasi berganda Adjusted R Square (Adj $\mathrm{R}^{2}$ ) sebesar 0,673 atau 67,3\%. Hal ini berarti 67,3\% variabel bagi hasil Deposito Mudharabah dapat dijelaskan oleh kedua variabel independen yaitu FDR dan NPF, sedangkan sisanya sebesar 32,7\% dijelaskan oleh sebab-sebab lain di luar model regresi yang digunakan.

\section{KESIMPULAN DAN SARAN}

Berdasarkan hasil penelitian pengaruh Financing to Deposit Ratio (FDR) dan NonPerforming Financing (NPF) terhadap bagi hasil Deposito Mudharabah pada Bank Syariah Mandiri periode 2011-2017, maka dapat ditarik kesimpulan sebagai berikut:

a. Hasil analisis variabel independen FDR dan NPF secara bersama-sama (simultan) mempunyai pengaruh signifikan terhadap variabel dependen, yaitu bagi hasil Deposito Mudharabah. Hal tersebut dapat dilihat dari tingkat signifikansi sebesar 0,000 lebih kecil dari 0,05 dan $F_{\text {hitung }}>F_{\text {tabel }}(28,799>3,39)$.

b. Berdasarkan koefisien regresi secara parsial terdapat pengaruh negatif dan signifikan variabel Financing to Deposit Ratio (FDR) terhadap bagi hasil Deposito Mudharabah yang ditunjukkan dengan $t_{\text {hitung }}<\mathrm{t}_{\text {tabel }}(-4,145<1,70113)$ dan tingkat signifikansi $0,000<0,05$. Jadi, hipotesis penelitian yang menyatakan bahwa variabel Financing to Deposit Ratio (FDR) berpengaruh signifikan terhadap variabel bagi hasil Deposito Mudharabah diterima. Hal ini dapat dilihat juga dari tingkat signifikansi variabel FDR sebesar 0,000 yang lebih kecil daripada tingkat signifikansi yang digunakan yaitu 0,05. Maka, kesimpulannya adalah FDR berpengaruh negatif terhadap bagi hasil Deposito Mudharabah.

Hasil ini tidak sesuai dengan teori yang menyatakan bahwa jika kualitas aset yang dicerminkan oleh FDR semakin meningkat, maka efektifitas pendapatan pada bank syariah dari earning asset akan semakin meningkat dan akibatnya akan meningkatkan bagi hasil yang dibagikan kepada nasabah. Oleh karena itu, hipotesis yang menyatakan bahwa FDR berpengaruh positif terhadap tingkat bagi hasil ditolak. 
c. Berdasarkan koefisien regresi secara parsial terdapat pengaruh positif dan signifikan variabel Non-Performing Financing (NPF) terhadap bagi hasil Deposito Mudharabah yang ditunjukkan dengan $t_{\text {hitung }}>t_{\text {tabel }}(2,507>1,70113)$ dan tingkat signifikansi $0,019<0,05$. Jadi, hipotesis penelitian menyatakan bahwa variabel Non-Performing Financing (NPF) berpengaruh signifikan terhadap variabel bagi hasil Deposito Mudharabah diterima. Hal ini dapat dilihat juga dari tingkat signifikansi NPF sebesar 0,019 yang artinya lebih kecil daripada tingkat signifikansi yang digunakan yaitu 0,05. Maka, kesimpulannya adalah NPF berpengaruh positif terhadap bagi hasil Deposito Mudharabah.

Hasil ini tidak sesuai dengan teori yang menyatakan bahwa jika kualitas aset yang dicerminkan oleh NPF semakin meningkat, maka efektifitas pendapatan pada bank syariah dari earning asset akan semakin berkurang dan akibatnya akan menurunkan bagi hasil yang dibagikan kepada nasabah. Oleh karena itu, hipotesis yang menyatakan bahwa NPF berpengaruh negatif terhadap tingkat bagi hasil deposito mudharabah ditolak.

Saran yang bisa diberikan terkait penelitian ini antara lain:

a. Penelitian ini hanya menggunakan satu sampel, yaitu Bank Syariah Mandiri. Oleh karena itu, untuk penelitian berikutnya disarankan agar menggunakan lebih banyak sampel dari seluruh bank umum syariah di Indonesia. Pada penelitian berikutnya juga disarankan untuk menggunakan variabel independen lain atau menambahkan beberapa variabel lain agar kajian penelitian menjadi lebih luas cakupannya termasuk yang terkait faktor-faktor memberikan pengaruh bagi hasil Deposito Mudharabah secara signifikan.

b. Bagi nasabah deposan disarankan untuk mencari informasi lebih rinci tentang tingkat bagi hasil Deposito Mudharabah, tingkat NPF, dan FDR sebelum menginvestasikan dananya pada bank syariah.

c. Bagi bank disarankan agar lebih memperhatikan tingkat rasio keuangan dan kinerja bank dalam hal memberikan tingkat bagi hasil agar mampu bersaing dengan bank konvensional untuk meningkatkan perolehan dana pihak ketiga yang dihimpun oleh bank syariah.

\section{DAFTAR REFERENSI}

Anshori, A. G. (2007). Perbankan Syariah di Indonesia. Cetakan Kesatu. Yogyakarta: Gadjah Mada University Press, h. 93-94.

Antonio, M. S. dkk. (2006). Bank Sayriah Analisis Kekuataan, Kelemahan, Peluang, dan Ancaman. Cetakan Kesatu. Yogyakarta: Ekonisia.

Karim, A. A. (2004). Bank Islam Analisis Fiqh dan Keuangan. Jakarta: PT Raja Grafindo Persada.

Karim, A. A. (2013). Bank Islam Analisis Fiqih dan Keuangan. Jakarta: PT Raja Grafindo Persada.

Bank Syariah Mandiri. Laporan Keuangan Tahunan Bank Syariah Mandiri. Diakses pada tanggal 20 November 2017 di http://www.syariahmandiri.co.id. 
Ismail (2015). Perbankan Syariah.

Iqtishadia (2017). Analisa Faktor-Faktor yang Mempengaruhi Tingkat Bagi Hasil Simpanan Mudharabah. Jakarta: Bank Umum Syariah.

Ismail (2011). Perbankan Syariah. Edisi I. Jakarta: Kencana.

Kasmir (2007). Manajemen Perbankan. Jakarta: PT Raja Grafindo Persada.

Al Arif, M. N. (2010). Dasar-Dasar Pemasaran Bank Syariah. Cetakan Kesatu. Bandung: CV Alfabeta.

Muhammad (2014). Manajemen Dana Bank Syariah. Yogyakarta: Ekonisia.

Nugraha, S. (2014). Pengaruh ROA, NPF, FDR, BOPO dan Tingkat Bagi Hasil terhadap Pembiayaan Mudharabah. Skripsi. UIN Syarif Hidayatullah. 